\title{
The Trial of Neville Heath, the Popular Press, and the Construction of the Memory of the Second World War in Britain, 1945-1946*
}

In the three decades after 1945, the cultural memory of the Second World War underpinned crucial elements of British politics, culture and society. It was central to the maintenance of a postwar political settlement defined by support for full employment, high welfare spending, and an active cold war foreign policy, and to bolstering cultural confidence in the context of faltering notions of national identity and widespread fears of economic and national decline. ${ }^{1}$ It is no exaggeration to describe the legacy of the war as the most important factor shaping the period many British historians still call the 'postwar', the years stretching from the election of Attlee's Labour Government in the summer of 1945 to the election of Thatcher's Conservative Government in 1979. Yet our knowledge of how the war was remembered, and especially the processes by which certain aspects of the war became entrenched within popular memory while other aspects were neglected, suppressed, or forgotten, is partial at best. Analyses of the cultural memory of the war naturally concentrate on those cultural productions which depicted the war itself. ${ }^{2}$ Comparing a large number of such productions allows historians to identify both broad trends in wartime memory and the exceptional cases when otherwise neglected narratives punctured more typical representations. However, the chronological specificity of these productions is often overlooked, or its significance

\footnotetext{
* I would like to thank Jeremy Krikler, Tracey Loughran, Nadine Rossol, Felix Schnell, and Stephanie Ward for reading earlier versions of this article, and the editors and anonymous peer reviewers of this journal for their extremely helpful and constructive suggestions.

${ }^{1}$ The literature on the impact of the postwar 'consensus' is extensive, but the key early work was P. Addison, The Road to 1945: British Politics in the Second World War (London, 1975); for a sustained critique see H. Jones and M. Kandiah, eds., The Myth of Consensus: New Views on British History, 1945-64 (Basingstoke, 1996); a more recent work is R.G. Hughes, The Postwar Legacy of Appeasement: British Foreign Policy since 1945 (London, 2014). On 'cultural confidence', see G. Eley, 'Finding the people's war: film, British collective memory and World War II', American Historical Review, 105 (2001), pp. 818-38; P. Summerfield, 'Public Memory or Public Amnesia? British Women of the Second World War in Popular Film', Journal of British Studies 48:4 (2009), pp. 935-57.

${ }^{2}$ See, for example: J. Ramsden, 'Refocusing “The People's War”: British War Films of the 1950s', Journal of Contemporary History 33:1 (1998), 35-63; Summerfield, 'Public Memory or Public Amnesia?'; L. Noakes and J. Pattinson, eds., British Cultural Memory and the Second World War (London, 2013).
} 
unrealised. Because such productions became common only at the end of the 1940s and into the 1950 s, they tell us little about the immediate postwar period. ${ }^{3}$ Historical scholarship on the cultural memory of the Second World War therefore tends both to neglect cultural forms which did not explicitly discuss the war, and the importance of the fact that the immediate postwar period was decisive in the formation of the memory of the war. ${ }^{4}$

This article examines how the cultural memory of the war was calibrated during the immediate postwar years, and argues that the eighteen months after VE Day were crucial to the formation of the war memory that would later became so firmly established within popular culture. In 1945 and 1946, anxiety about the consequences of the war was inescapable in press discussions of British political, economic and social life. The nation's precarious financial position in 1945 was coupled with a global food and refugee crisis in the winter of $1945-46$ to create the impression of a Britain on the brink of disaster. ${ }^{5}$ In social terms, popular newspapers were full of stories of broken marriages and an increase in violent crime. These two trends combined in spectacular fashion with a number of high-profile cases of returning servicemen murdering their supposedly unfaithful wives. Such violence was juxtaposed with ongoing discussions of the war crimes of German and Japanese forces, which seemed to raise fundamental questions about the humans capacity for evil. By the end of 1946, I argue, the legacy of wartime violence was increasingly framed in the popular press as having little import for Britain's long-term well-being. Such crimes were now understood as part of a complex process of economic reconstruction and partial social dislocation, but they were not considered as an indicator of deep-rooted psychological effects. The process by which this understanding of the impact of the war was established within the nascent memory

\footnotetext{
${ }^{3}$ Penny Summerfield has written on how the transition from war to peace was remembered by later oral history participants: "It Did Me Good in Lots of Ways": British Women in Transition from War to Peace', in C. Duchen and I. Bandhauer-Schoffman, eds., When the War Was Over: Women, War, and Peace in Europe, 19401956 (London, 2000), pp. 14-28.

${ }^{4}$ T. Judt, 'The Past is Another Country: Myth and Memory in Postwar Europe', Daedalus 121:4 (1992), p. 86.

${ }^{5}$ See J. Tomlinson, 'Churhcill and Britain's "Financial Dunkirk"', Twentieth Century British History, 15:4 (2004), pp. 329-60.
} 
of the war during 1945 and 1946 is analogous to the construction of a 'usable past', which historians have identified as allowing continental European to deal with the traumatic legacies of war. This occurred through the creation of 'usable' versions of the past that downplayed histories of defeat, occupation and genocide and instead attempted to naturalise national stories of individual domesticity and privacy, and collective hope or grievance. ${ }^{6}$ Similar narratives have been identified as allowing Britain to recover from the First World War. ${ }^{7}$ After 1945, however, Britain had no comparable traumatic past to 'make usable', but troubling wartime experiences did hold the potential to hinder positive images of postwar Britain as a strong and unified nation which were central to the reconstruction efforts after $1945,{ }^{8}$ and which have underpinned British cultural and political identity into the twenty-first century. ${ }^{9}$ In Britain, as in Europe, the cultural memory of the Second World War was refashioned through popular culture to eliminate or reduce perceptions of the potentially negative consequences of the war, and instead to accentuate its positive aspects. Crucially, this remembering and forgetting of the war occurred across a range of cultural productions that were not explicitly or obviously concerned with the war itself, but rather attempted to make sense of the concrete realities of the postwar world. Cultural memory is not formed through a process of outright suppression, at least not solely. ${ }^{10}$ As Aleida Assman puts it,

\footnotetext{
${ }^{6}$ For exemplary examples of 'postwar' European history, see R. Moeller, War Stories: The Search for a Usable Past in the Federal Republic of Germany (Berkeley, 2001); M. Conway, The Sorrows of Belgium: Liberation and Political Reconstruction, 1944-1947 (Oxford, 2012); P. Lagrou, 'Victims of Genocide and National Memory: Belgium, France and the Netherlands, 1945-65', Past and Present 154 (1997), pp. 181-222; see also the essays in two recent collections: R. Bessel and D. Schumann, eds., Life After Death: Approaches to a Cultural and Social History during the 1940s and 1950s (Cambridge, 2003); F. Beiss and R.G. Moeller, eds., Histories of the Aftermath: The Legacies of the Second World War in Europe (Oxford, 2010).

${ }^{7}$ See, in particular, A. Light, Forever England: Femininity, Literature, and Conservatism between the War (London, 1991).

${ }^{8}$ B. Conekin, F.Mort, and C. Waters, eds., Moments of Modernity: Reconstructing Britain, 1945-1964 (London, 1999); B. Conkein, The Autobiography of a Nation: the 1951 Festival of Britain (Manchester, 2003); R. Hornsey, The Spiv and the Architect: Unruly Life in Postwar London (Minneapolis, 2010).

${ }^{9}$ D. Reynolds, 'Britain, the Two World Wars, and the Problem of Narrative', Historical Journal, 60:1 (2017), pp.197-231.

${ }^{10}$ F. Beiss, 'Introduction: Histories of the Aftermath', p. 3.
} 
'there is no self-organisation and self-regulation of cultural memory - it always depends on personal decisions and selections, on institutions and media'. ${ }^{11}$

In histories of defeated and/or occupied Europe, the process by which a usable past is created is associated with a timeframe after the immediate period of liberation, occurring later in the 1940s. ${ }^{12}$ Here I use press coverage of the 1946 murder trial of Neville Heath as a case study to demonstrate how this process could begin in its early stages. Through analysing the press coverage of trial, it is possible to show how the popular media treated the potential effects of the war, particularly the existence of 'evil' or 'sadistic' violence, highlighting explanations for Heath's crimes that can be seen to have protected more positive representations of the war. By unpicking the subtly different ways in which the war was understood in the press coverage of this particular trial, I aim to contribute to wider scholarship on war and memory by illuminating the processes through which a usable past could begin to be created in specific historical conditions. The challenge of this task is to show that the selective depiction of the war within the press was an act of narration which expressed cultural anxieties, and that newspapers performed the important work of constructing a usable past.

High profile court cases have been used by several modern British historians to analyse deep-seated social and cultural anxieties. Historians such as Judith Walkowitz, Matt Houlbrook, and Frank Mort have used sensational criminal cases to examine how sexuality and morality were discussed within popular culture throughout the nineteenth and twentieth centuries. ${ }^{13}$ Several historians have investigated the press treatment of murder cases in the

\footnotetext{
${ }^{11}$ A. Assman, Cultural Memory and Western Civilisation (Cambridge, 2011), p. 6.

${ }^{12}$ P. Lagrous, The Legacy of Nazi Occupation: Patriotic Memory and National Recovery in Western Europe, 1945-1965 (Cambridge, 2000).

${ }^{13}$ For excellent examples, see: Judith R. Walkowitz, City of Dreadful Delight, (Second Edition, London, 1992);

R. Crone, Violent Victorians: Popular Entertainment in Nineteenth Century London (London, 2012); Lewis Perry Curtis, Jack the Ripper and the London Press, (New Haven, 2001); L. Bland, 'The Trials and Tribulations of Edith Thompson: the Capital Crime of Sexual Incitement in 1920s England', Journal of British Studies, 47:3 (2008), pp. 624-48. M. Houlbrook, "A Pin to See the Peepshow": Culture, Fiction and Selfhood in Edith Thompson's Letters, 1921-1922', Past and Present, 207 (2010), pp. 215-249; J. Carter Wood, 'The Most
} 
1950s in order to argue that there was a shift towards more explicit and open discussion of sexual issues in that decade. ${ }^{14}$ Whereas the Heath case has been discussed briefly by historians examining wartime anxieties about damaged servicemen, ${ }^{15} \mathrm{I}$ argue that a more detailed analysis of the case within its context shows that newspapers used a range of narrative methods to make sense of the Heath case. Its content was presented within the genre conventions of court reportage, and many of the case's sexual and criminal characteristics fitted the standard template of newspaper coverage.

The extremity of Heath's violent and sadistic acts raised questions about the potential relationship between war service and violence within British societies. I argue that newspapers explained Heath's acts to their readers by narrating them and his character in ways which downplayed Heath's military service and essentially set him apart from contemporary discussions about the violence of servicemen and the impact of the war on British society. His violence and sadistic urges were depicted as monstrous, and were explained in language similar to that used when reporting German and Japanese war crimes. As such, Heath was not treated as comparable to any other British criminal, but (discursively at least) like the German and Japanese 'monsters' who were heavily featured in 1945 and 1945. He was also pathologised as an almost unique type through emphasis on his criminal and sexual character, whereas servicemen's criminality more generally was often explained in wider press discussions as a result of the temporary dislocations brought about by war. Located in the broader context of the 'short postwar period', the press coverage of the Heath trial therefore becomes a highly suggestive case study with which to excavate meanings

Remarkable Woman in England': Poison, Celebrity and the Trials of Beatrice Pace (Manchester, 2012); Mort, Capital Affairs.

${ }^{14}$ Bingham, Family Newspapers?; Frank Mort, Capital Affairs:, pp. 137; E.L. Jones and N. Pemberton, 'Ten Rillington Place and the Changing Politics of Abortion in Modern Britain', Historical Journal 57:4 (2014), pp. 1085-1109.

${ }^{15}$ C. Emsley, Soldier, Sailor, Beggarman, Thief: Crime and the British Armed Services since 1914 (Oxford, 2013); A. Allport, Demobbed: Coming Home After the Second World War (New Haven, 2009); M. Francis, The Flyer: British Culture and the Royal Airforce, 1939-1945 (Oxford, 2008). 
about how social and cultural consequences of the war were debated in this distinctive moment of transition between war and peace.

\section{[Line space]}

Neville Heath murdered Margaret Gardner and Doreen Marshall in the summer of 1946. Gardner was killed on the night of 21 June 1946, her body found at a Notting Hill hotel after she had been tied, whipped, strangled and subsequently mutilated. The police immediately identified Heath, a former RAF pilot, as a suspect. He had signed into the hotel under his own name, had been seen drinking with the victim and a taxi driver had dropped them both off at the hotel in question. The police launched a national manhunt to track Heath down. While on the run, he killed Marshall, a recently de-mobilised Wren, in the popular seaside resort of Bournemouth. Marshall disappeared on 3 July and her mutilated body was discovered in a secluded spot in a Bournemouth 'chine' (a steep, wooded path from the cliff to the beach) on 7 July. Heath had been arrested the day before the discovery. He was eventually charged with both murders, and made preliminary appearances in court during July and August as he was committed to trial. The trial opened at the Old Bailey on 24 September 1946, with the prosecution providing insurmountable evidence that Heath had killed both women. Heath's defence rested on the claim that although he was responsible for both deaths, he was insane and so should escape hanging. The defence team pointed to the sheer ferocity and sadistic nature of the attacks, arguing that no 'sane' man would do such things. They also introduced Heath's criminal past, a legacy of frauds, thefts and deceptions dating back to his youth and encompassing three separate courts-martial and dismissals from service, the first occurring before the war had even broken out. Finally, they also pointed to a traumatic episode during Heath's war service, when he was forced to bail out of a bomber over Holland, as a reason for 
the 'blackouts' that led to his crimes. The jury rejected this plea, and Heath was found guilty and sentenced to death. He was hanged at Pentonville Prison on 16 October $1946 .{ }^{16}$

The trial of Neville Heath was by far the most sensational criminal case of the immediate postwar period. From the very beginning, it received extensive press coverage. The popular daily and London evening press maintained running commentary on the case over several months, while mass-market Sunday papers competed to shed new light on aspects they thought would fascinate readers. Although far from the only murders committed that summer, the depth of coverage of the Heath case was truly singular. It featured on the front page of every national popular newspaper, ${ }^{17}$ and during the trial newspapers devoted as many as four pages to the story when total pagination could be as little as eight pages. The scale of press interest in the case is explained by its sensational nature, above all because of the extremity of its violent and sexual content. Heath was depicted both as a sexual adventurer, and as a deranged, uncontrollable sadist. He had led an eventful life: he had joined the forces three different times under different names, on each occasion eventually being court-martialled and dismissed. He deserted from the ship taking him back to Britain after his second court-martial while it was docked in Durban. While in South Africa, he had led a playboy lifestyle, living off wealthy women before marrying and quickly divorcing the daughter of a local magnate. The press focus on the Heath case was deepened by the drawnout nature of the case. There was a manhunt lasting several days, and the search for Doreen Marshall was also heavily covered. Therefore, the murders of both Gardner and Marshall were high profile even before they were formally linked. Their linkage brought two cases

\footnotetext{
${ }^{16}$ By far the most comprehensive and well-researched of the many books on Heath is S. O'Connor, Handsome Brute: the True Story of a Ladykiller (London, 2013). Others, from the salacious to the very salacious, include: S. Brock, The Life and Death of Neville Heath (London, 1947); G. Byrne, Neville Heath: Borstal Boy, (London, 1954); F. Selwyn, Rotten to the Core: the Life and Death of Neville Heath (London, 1988); N. Root, Frenzy! Heath, Haigh and Christie: the First Great Tabloid Murderers (London, 2011).

17 The popular national daily newspapers were: Daily Express, Daily Herald, Daily Mail, Daily Mirror, Daily Graphic, and News Chronicle; the popular national Sunday newspapers were: News of the World, The People, Reynolds News, Sunday Dispatch, Sunday Express, Sunday Graphic, and Sunday Pictorial. I also make use of the three London evening newspapers: the Evening Standard, Evening News, and Star.
} 
together, and combined with the figure of Heath meant that when the case reached the Old Bailey press coverage became frenzied.

Fortuitously for newspaper proprietors, wartime printing restrictions were partially lifted the week the trial began. For the first time since the war, newspapers could print as many copies as the public demanded, and they were also allowed to increase the number of pages in each edition. The Heath trial therefore took place at a moment when loosening controls injected a new element of competition into the newspaper market, and so it became a centrepiece in the first week of a battle for new readers which saw an extraordinary boom in the circulation of newspapers in the late 1940s. The best-selling dailies, the Mirror and the Express, and the most popular Sundays, the News of the World, the People, and the Sunday Pictorial all had daily circulations over 2 million copies in the late 1940 s. ${ }^{18}$ Such vast readerships meant that Heath's crimes and his story entered virtually every home in Britain on multiple occasions in the summer and autumn of 1946, and at the time of the trial the social research organisation Mass-Observation found that Heath was one of the most famous men in Britain, his name instantly recognised by the public. ${ }^{19}$

As Adrian Bingham points out, criminal cases, particularly those with a sexual element, were a staple of mid-twentieth-century popular British newspapers. ${ }^{20}$ Since the late nineteenth century, the popular Sunday press had been particularly associated with detailed discussions of criminal trials, with the News of the World particularly notorious for printing the most detailed accounts of sexual misadventure or violence. ${ }^{21}$ However, the press boxes of the judicial system were also filled with journalists from the popular daily and evening

\footnotetext{
${ }^{18}$ Bingham, Family Newspapers?, p. 19; A. Bingham and M. Conboy, Tabloid Century: the Popular Press in Britain, 1896 to the Present (Oxford, 2015).

${ }^{19}$ Mass-Observation Archive, University of Sussex. Topic Collection 14, 'Famous Persons, 1938-1952', 1.K, 'Neville Heath'.

${ }^{20}$ A. Bingham, Family Newspapers? Sex, Private Life, and the British Popular Press, 1918-78 (Oxford, 2009), p. 130.

${ }^{21}$ However, as Kate Bradley has shown, the News of the World had much more depth than its stereotypical depiction as a scandal-focused rag suggests. See K. Bradley, “All Human Life is There": the John Hilton Bureau of the News of the World and Advising the Public, 1942-1969', English Historical Review 129:539 (2014), pp. 888-911.
} 
newspapers. Because newspapers could rely on direct and lengthy quotations from witness and lawyer statements to convey the most salacious details of any case under the guise of reportage, trials helped to sell newspapers while allowing editors to distance themselves from accusations of scurrility. As such, sensational court reports allowed newspapers to combine titillation with moral calls for the upholding of the law, respect for the police, and the preservation of traditional morality. ${ }^{22}$ The Heath trial, like all cases that were especially or unusually sexual or violent, obviously made for good copy. ${ }^{23}$ It was presented to the public by newspapers in the highly stylised form of court proceedings which were already notably theatrical in staging. ${ }^{24}$ Court reportage was obviously far from neutral: journalists deliberately narrated those aspects of the case they believed would appeal to readers and made no attempt to present an unvarnished record of court proceedings. Some stories were seized on, others left by the wayside. We can see this by comparing newspaper accounts of the Heath trial to the trial transcript produced in 1951 for the publisher William Hodge's 'Notable British Trials' series, based on the shorthand record of the trial. ${ }^{25}$ The full version of the trial transcript, however, remains classified and is absent from the redacted case files held in the UK National Archives. ${ }^{26}$ We therefore have a reasonably full text of the trial with which to compare different newspapers' treatment of the case, but we certainly have no definitively 'true' record of the Old Bailey proceedings.

We can only understand the trial in the contexts of the wider discussion surrounding crime and violence in Britain after the Second World War. Although the Heath case took place in a context in which there was great anxiety about postwar crime, concerns about the psychological effects of war were implicit in newspaper coverage. One reason for the lack of

\footnotetext{
${ }^{22}$ Bingham, Family Newspapers?, p. 130.

${ }^{23}$ T. Thomas, Sex Crime: Sex Offending and Society, (Portland, 2000), p. 16

${ }^{24}$ N. Erber and G. Robb, 'Introduction', in their eds., Disorder in Court: Trials and Sexual Conflict at the Turn of the Century (Basingstoke, 1999), p. 6.

${ }^{25}$ M. Critchley, ed., The Trial of Neville George Clevely Heath, (London, 1951), p. vii.

${ }^{26}$ The National Archives, Kew. HO 144/22872. 'Criminal Cases: Heath, Neville George Clevely'.
} 
explicit discussion is that there was an assumption that such impact had been relatively minimal. Major pre-war anxieties about the psychological effects of war for both civilians and for servicemen had proved relatively unfounded: fears of collective hysteria in the face of enemy bombing marked planning for war, and the legacy of shell shock in the First World War hung heavily over the military in the build up to the Second, ${ }^{27}$ although the experience of Prisoners of War, particularly in the Far East, was an exception to this. During the war itself, psychological trauma was present but rarely publicised, and its diagnosis actively discouraged within medico-military circles. ${ }^{28}$ Within popular culture, the dominant ideology of national unity, self-sacrifice and togetherness mitigated against discussion of the traumatic experiences of war. As Angus Calder put it in his path-breaking 1992 volume, The Myth of Blitz, the model of the 'Cheerful Cockney' smiling through the blitz became a symbol of stoicism in the face of enemy attack and a model for others to follow whatever fears were felt inwardly. ${ }^{29}$ In the years following on from the end of the war, this image of the nation at war forged in 1940 became entrenched as the basic narrative of the wider cultural memory of the conflict. Recent historical work, however, has emphasised the extent to which acute fear and grief were present but supressed in public during the war, ${ }^{30}$ a result of a culture which emphasised 'public morale rather than private sorrow', in Pat Jalland's words. ${ }^{31}$ In 1945 , however, there was certainly far less concern about the psychological efforts of war than there had been in 1939, and as Ben Shepherd has argued any concern about the psychological effects of the war on soldiers was forgotten in the face of concerns about the reconstruction of

\footnotetext{
${ }^{27}$ See, for example, M. Thomson, Psychological Subjects: Identity, Culture, and Health in Twentieth Century Britain (Oxford, 2006); B. Shephard, A War of Nerves: Soldiers and Psychiatrists, 1914-1994 (London, 2002), p. 327.

${ }^{28}$ B. Shephard, "Pitiless Psychology": the Role of Prevention in British Military Psychiatry in the Second World War', History of Psychiatry, 10 (1999), pp. 491-524; E Jones, "LMF”: the Use if Psychiatric Stigma in the Royal Air Force during the Second World War', Journal of Military History, 70 (2006), pp. 439-58.

${ }^{29}$ A. Calder, The Myth of the Blitz (London, 1992), pp. 124-5.

${ }^{30}$ A. Bell, 'Landscapes of Fear: Wartime London, 1939-1945, Journal of British Studies, $48: 1$ (2009), L. Feigel, The Love-Charm of Bombs: Restless Lives in the Second World War (London, 2013); G.G. Field, Blood, Sweat and Toil: Remaking the British Working Class, 1939-1945 (Oxford, 2011).

${ }^{31}$ P. Jalland, Death in War and Peace: a History of Loss \& Grief in England, 1914-1970 (Oxford, 2010), p. 59
} 
Britain's economy and phsycial environment. ${ }^{32}$ In this respect, it could be argued that Britain followed general European trends: Frank Beiss has argued that throughout Europe, reconstruction was based on an 'optimistic, forward-looking perspective that emphasised over-coming and selective remembering' aided by a 'transnational psychiatric culture that largely denied any lasting damage' caused by wartime experiences. ${ }^{33}$

There were some clear and visible anxieties in Britain, of course. Social surveys on the experience of evacuation highlighted the behaviour problems caused by separation for families. Influential child psychiatrists such as John Bowlby argued in the post war that the war did indeed have profound implications, arguing that personality disorders became entrenched at a young age, and that the displacement of war, especially the separation of mothers from their children, might result in future delinquency. ${ }^{34}$ In the postwar period, these arguments profoundly influenced attitudes towards working mothers and "problem families', ${ }^{35}$ and depictions of youthful criminality (centring on the 'spiv' figure) often the showed the criminal as a victim of a troubled upbringing. ${ }^{36}$ There were also deep concerns about the return of servicemen into civilian life, as Alan Allport has shown, ${ }^{37}$ but these fears were particularly concerned with economic and family life. In the popular press, advice columns and features produced from 1944 and extending into early 1946 debated how

\footnotetext{
${ }^{32}$ Shephard, A War of Nerves, p. 327.

${ }^{33}$ F. Beiss, 'Introduction: Histories of the Aftermath', p. 3.

${ }^{34}$ M. Shapira, The War Inside: Psychoanalysis, Total War and the Making of the Democratic Self in Post-War Britain (Cambridge, 2013); M. Thomson, Lost Freedom: The Landscape of the Child and the British Post-War Settlement (Oxford, 2013). Bowlby produced a report for the World Health Organisation based on a Europewide survey of children who were orphans or otherwise separated from their families: see 'Maternal Care and Mental Health', special number of Bulletin of the World Health Organisation, 3:3 (1951), pp. 357-533.

${ }^{35}$ P. Starkey, 'The Feckless Mother: Women, Poverty and Social Workers in Wartime and Post-war England', Women's History Review, 9:3 (2000), pp. 539-57; D.S. Wilson, 'A New Look at the Affluent Worker: the Good Working Mother in Post-war Britain', Twentieth Century British History, 17:2 (2006), pp. 206-29.

${ }^{36}$ A. Wills, 'Delinquency, Masculinity and Ccitizenship in England, 1950-70', Past and Present, 187 (2005), pp. 157-86; Hornsey, The Spiv and the Architect; R. Murphy, Realism and Tinsel: Cinema and Society in Britain, (London, 1989), pp. 126-45.

${ }^{37}$ Allport, Demobbed.
} 
veterans would fit back into peacetime society, creating the impression that the war would have profound consequences for British society. ${ }^{38}$

These anxieties were particularly expressed in relation to the widespread discussion of an increase in crime during the second half of 1945. Although crime statistics show that the postwar period saw no increase in murders from the war years, ${ }^{39}$ many high profile cases involving violent veterans featured in newspapers after 1945. The most publicised of these involved the murder of apparently unfaithful wives by returning servicemen and their acquittal by sympathetic juries. These led to anxious discussion concerning the 'law of the jungle' or 'unwritten law', as returning servicemen appeared to be taking the law into their own hands and exacting retributive violence on their wives. ${ }^{40}$ The press treated these cases ambiguously, emphasising any concerns expressed from the bench about the social fabric of the nation while simultaneously framing the cases around narratives of wartime marriage and separation. Newspaper reports appeared to align themselves with the juries and often placed the blame squarely on 'adulterous' wives rather than their 'betrayed' husbands, who were depicted as wronged heroes who sought to defend domestic values rather than as men transformed by the war. Press treatment of such cases implied that crime, and violence more generally, represented temporary difficulties in adjusting to peace rather than the transfer of wartime violence to the peacetime home front. Such crimes were less common in the first half of 1946, and were much less likely to be reported in depth when they did occur. In one relatively late example, a case reported at the same time as the Heath manhunt, the News of the World presented Frederick Burt's homicidal knife attack on his wife as understandable given her adultery. Burt was cleared of murder but convicted of manslaughter, ${ }^{41}$ and the case

\footnotetext{
${ }^{38}$ A typical example is: N. Wibberley, 'One Man Hunts His Job', Daily Express, 2 Jan. 1946, p. 2.

${ }^{39}$ Home Office, Criminal Statistics: England and Wales, 1946, Cmd.7428 (HMSO, 1948), p. xvi.

${ }^{40}$ Allport, Demobbed, pp. 163-85.

41 'Killed Wife Whom He Worshipped', News of the World, 7 Jul. 1946, p. 2.
} 
bore all the hallmarks of earlier trials. The story, however, was not picked up in most of the dailies, and the News of the World did not accord it great prominence.

There was also a deeper sense of a postwar crime wave, involving robberies committed by organised gangs of deserters, fears about which peaked in December $1945 .{ }^{42}$ In fact, David Kynaston has argued that 'a moral panic was brewing up nicely' in the weeks before Christmas in $1945 .{ }^{43}$ Historians have explained the increase in crime due as a result of temporary social and economic dislocation: shortages of goods through scarcity and continued rationing meant that theft had never been more profitable; deserters were forced into a life of crime due to their lack of documentation, and Police forces had not yet recovered from wartime reductions in manpower, meaning that criminals were less likely to be caught. ${ }^{44}$ In the press, it was often implied that the loosening of male authority within the home caused by mass mobilisation had stimulated ordinary criminals and 'young delinquents' to pursue the opportunities for easy excitement and profit offered by the war. The remedy for dealing with such crime involved fast police action, but also, as a Reynold's News story put it, a 'return at the earliest possible moment to conditions that promote good social behaviour'. ${ }^{45}$ In particular, it was widely assumed that only a return to normal economic activity and the abolition of rationing could completely eliminate the criminal black market. ${ }^{46}$ As such, press anxiety about crime and delinquency again tended to focus on the dislocation caused by the war, rather than any apparently traumatic events of the war itself, and assumed that the process of reconstruction the nation was undertaking would

\footnotetext{
42 'Yard Call Trade Chiefs to Crime Wave Talks', Daily Mirror, 8 Dec. 1945, p. 1; 'The Cause of Crime', Daily Mail, 11 Dec. 1945, p. 2; 'Police Bag in Great Comb Out', News of the World, 16 Dec. 1945, p. 1; 'London Violence Has Increase by 100 p.c.', Daily Mirror, 21 Dec. 1945, p. 8.

${ }^{43}$ D. Kynaston, Austerity Britain, 1945-51(London, 2007), p. $113 .$.

${ }^{44}$ See M. Roodhouse, Black Market Britain, 1939-1955 (Oxford, 2013); A.H. Bell, Murder Capital: Suspicious Deaths in London, 1933-1953 (Manchester, 2015), p. 4

${ }^{45}$ E. Glover, 'Truth about the Murder Wave', Reynolds News, 14 Jul. 1946, p. 2; see also "Crime and Society," The Listener, 14 Feb. 1946, p. 200.

${ }^{46}$ Roodhouse, Black Market Britain.
} 
resolve such problems. ${ }^{47}$ and although press stories about a 'crime wave' continued into $1946,{ }^{48}$ there was less sense within the press that postwar crime signified wider social problems. The link between crime and reconstruction reflected intense and ongoing concerns about the ability of Britain to recover economically in this period. The summer of 1946 saw the Government introduce bread rationing for the first time. At the same time, a desperatelyneeded loan from the United States made its slow progress through Congress, generating ambivalent coverage in the press because it was resented as a symbol of British weakness. ${ }^{49}$

Clive Emsley has argued that evidence of 'brutalised, violent criminals' is hard to find in the postwar period, ${ }^{50}$ and this is borne out in newspaper coverage of murder trials. Occasionally, the criminal cases reported in the press featured men who, like Heath, claimed diminished responsibility through war-induced conditions such as blackouts and trauma. These were, however, relatively small in number, in contrast to the aftermath of the First World War, when the pleas of insanity due to shell shock were common. ${ }^{51}$ Whereas men who killed their wives received sympathy for their emotional distress, men who committed different crimes here held firmly to account and pleas of war trauma were usually rejected. In the spring of 1946, for example, Stanley Hoff was convicted of killing Marjorie Hoff after suffering 'headaches' since being discharged from the army. ${ }^{52}$ In the same week Hoff was convicted, another veteran had his plea dismissed when the judge wondered that if 'your war experiences have unsettled you... I have to ask myself what is to happen until you do settle'. ${ }^{53}$ There was little sympathy in the courtroom or in the press. It was less common than

\footnotetext{
${ }^{47}$ See Hornsey, The Spiv and the Architect.

48 'Report on Crime', Daily Express, 20 May1946, p. 2; Mr Justice Humphreys, 'The Crime-Wave', Sunday Graphic, 4 Aug. 1946, p. 4.

${ }^{49}$ See R. Toye, 'Churchill and Britain's "Financial Dunkirk”, Twentieth Century British History, 15:4 (2004), 329-60.

${ }^{50}$ C. Emsley, Soldier, Sailor, Beggarman, Thief, p. 173; see also Allport, Demobbed, p. 185

${ }^{51}$ E.T. Dean, 'War and Psychiatry: Examining the Diffusion theory in the light of the insanity defence in postWorld War I Britain', History of Psychiatry, 4 (1993), pp. 61-82; For the wider context of shell shock, see T. Loughran, Shell Shock and Medical Culture in First World War Britain (Cambridge, 2016).

52 'Insanity Plea for Young Father Fails', News of the World, 12 May 1946, p. 5.

53 'Problem of War Veteran's Bad Habits', News of the World, 12 May 1946, p. 2.
} 
otherwise for insanity pleas to be presented as having any significant link to military service. In September 1945, for example, George Turner was given a five years sentence for 'criminally assaulting' two women. Turner had declared that 'when I go out with a girl alone I get an obsession that I want to get hold of her throat and strangle her', and argued that he was experiencing blackouts caused by a concussion experienced two years previously. ${ }^{54}$ In November 1945, John Young was convicted of murder despite a plea that 'a demon' inside him. ${ }^{55}$ In February 1946, a prison doctor declared that Ernest Clarke was sane at his murder trial, 'although obviously suffering from neurasthenia'. Although Clarke had served in the army and had briefly been a prisoner of war, this service was not linked to his mental health in the press. ${ }^{56}$ In another trial, it was emphasised that Meryvn Oliver had been sexually abused at school and was 'a psychopathic case'. His exemplary service in the RAF was taken as example of his good character before his 'relapse' into crime. ${ }^{57}$ These examples show that by the summer of 1946, newspaper readers would have read about a wide variety of crimes committed by servicemen. Yet, the handling of such cases in courts and the press emphasises that such violence was often perceived as a result of temporary wartime dislocation, and that the reconstruction of 'normal' economic and family life would see a reduction of crime. Moreover, there was a definite reduction in the number of violent crimes associated with returning veterans in the first half of 1946 compared to the latter half of 1945. Equally, violence by apparently disturbed men was by no means automatically associated with those returning from service.

At the Old Bailey in September 1946, Heath was tried only for the murder of Margaret Gardner (it was standard at the time for only one murder charge to be taken to trial). His defence counsel introduced the second murder and Heath's previous criminal record in

\footnotetext{
54 'Sailors' Obsession to Strangle Girls', News of the World, 16 Sep. 1945, p. 2.

55 'Not my Murder but a Demon's', Daily Express, 9 Nov. 1945, p. 3.

56 'Strangled Wife Was Once "Pen Pal"', News of the World, 3 Feb. 1946, p. 5

57 'Ex-Pilot's Relapse into Crime', News of the World, 3 Mar. 1946, p. 7.
} 
order to prove his 'partial insanity' ${ }^{58}$ As Heath offered no other defence, the trial came down to whether Heath was insane according to the long-standing Macnaughten rules governing legal responsibility. Put simply, the rules asked: did the defendant know what he was doing, and if so, did he know it was wrong? If the answer to either question was yes, Heath had to hang. Heath's defence counsel, J.D. Casswell KC, argued that a normal reaction to the case was to think, 'the man must be mad. Can you believe it was a mere sadist or a dishonest man who did these things? That man surely was as mad as a hatter; absolutely insane; a maniac can he have been anything else?' ${ }^{59}$ He called William Hubert, a psychiatrist with long experience working with criminals, as an expert medical witness. Hubert, although confident in his assertion that Heath was 'morally insane', gave a confused performance on the witness stand, suggesting that all criminals who felt they could justify their crimes, whether murder or the passing of a bad cheque, were equally free from responsibility. The prosecuting counsel, Anthony Hawke, called two prison doctors as witnesses: both declared Heath sane enough to hang. Hawke argued 'no one suggests that this is a normal person we are dealing with', but if the defence claim was accepted then 'everybody who acted in an abnormal way... would be able to say "I am not responsible for what I did"' ${ }^{60}$ The judge, Mr Justice Morris, perhaps agreed, telling the jury during his summing up: 'the law of insanity is not to become a refuge of those who cannot challenge a charge which is brought against them... mere love of lust, and inability to resist temptation is not in itself insanity'. ${ }^{61}$

Caswell's case fell down both because of Hubert's inability to convince the jury, and also because he had no real evidence for any 'disease of mind' or identifiable turning point in Heath's life. There was no evidence presented of sadism or violence at a younger age, which would have allowed Heath to be declared 'morally defective'. Instead, Caswell attempted to

\footnotetext{
${ }^{58}$ For full details of Heath's defence, see Critchley, ed., The Trial of Neville George Clevely Heath.

59 'Insanity Plea Not a Refuge: Says Heath Trial Judge', Daily Graphic, 27 Sep. 1946, p. 4.

60 "'I Say That Heath is Not Insane", Prison Doctor Tells Jury', Daily Express, 26 Sep. 1946, p. 3.

61 'Judge's Voice Fell to a Whisper... Then Came the Words of Doom', Daily Mirror, 27 Sep. 1946, p. 3.
} 
argue that Heath's sadistic violence could be linked to the wartime episode in which he was forced to bail out of a malfunctioning bomber while flying over liberated Holland. This event had apparently exacerbated his already unstable mental state, which Caswell illustrated by revealing Heath's record of fraud and deception to the jury. When summing up, Caswell told the jury: 'the human frame was not built to fly in machines and be fired at' and that they might conclude 'that that kind of experience may have something to do with the outburst, the admitted outbursts, of sadism in this man after the war was over' ${ }^{62}$ This conclusion is accepted by Heath's latest biographer, Sean O'Connor, who argues that this incident triggered trauma-induced blackouts during which his violent crimes were committed, and declares Heath to be 'a casualty of historical forces beyond his control' ${ }^{63}$ However, it was rejected by the jury.

It was also rejected by the press. Or rather, it was largely ignored. The section of Caswell's closing statement concerning Heath's traumatic experiences was not reported by any national newspaper, and mentioned only briefly in one London evening newspaper, the Evening News. ${ }^{64}$ Although the trial was reported in enormous depth, with set-piece speeches and important evidence relayed in immense detail, the press departed from the trial transcript by ignoring the key defence argument that traumatic wartime experiences had led to Heath's mental instability. The two other London evening newspapers printed Caswell's closing statement virtually verbatim, apart from this section. ${ }^{65}$ This was a narrative choice on the part of the press. It is as if the court and the popular press refused to countenance the idea that Heath's wartime experience contributed to his crimes. As we have seen, pleas of war-induced insanity were relatively rare in this period, and were not heard sympathetically. The sadism and violence of the murders Heath committed were exceptional, and certainly could not be

\footnotetext{
${ }^{62}$ Critchley, ed., The Trial of Neville George Clevely Heath, p. 188.

${ }^{63}$ O'Connor, Handsome Brute, p. 389.

64 'Last Plea for Heath: Insane', London Evening News, 26 Sep. 1946, p. 1.

65 'Defence K.C. Says "He is Not a Man to Go Free"', London Star, 26 Sep. 1946, p. 4; 'Heath to Die: Judge Tells Jury "Mere Lust is Not Insanity”, London Evening Standard, 26 Sep. 1946.
} 
fitted into discursive norms for portraying ex-service killers which emphasised domestic passion and disturbance. Nor were Heath's limited wartime experiences unique, or even severe, compared to those of other airmen. In fact, the press was largely uninterested in Heath's military career, discussing it after the trial mainly in relation to the thefts, frauds and deceptions he committed while in uniform. ${ }^{66}$ Before and during the trial, Heath was essentially de-militarised: he was most often described simply as a 'pilot', or even a 'civil pilot', rather than as a former serviceman. ${ }^{67}$

Instead, Heath's sadism was placed at the centre of newspapers' coverage throughout the case. ${ }^{68}$ The injuries inflicted on Doreen Marshall meant that before the trial had even begun, the description of the murders as 'sadistic' was entrenched in the press, with the killer compared to both Jack the Ripper and Jekyll and Hyde, ${ }^{69}$ and the press hinting that the 'horrible, sadistic injuries' were too awful to be described. ${ }^{70}$ Once the trial opened, and the press pored over the case in graphic detail, the sadistic nature of the killings was invoked as a key explanatory factor: Heath was a 'sadist', a 'monster', a 'snarling animal' who killed to satisfy his perverted desires. ${ }^{71}$ All three London evening papers led with stories on the Heath trial on each of the three evenings the case was at the Old Bailey. All, even the usually restrained Evening Standard, concentrated on the 'sadistic', 'perverted' and 'brutal' aspects

\footnotetext{
${ }^{66}$ See "Heath - "The Kind Who Lives for the Moment, and Deceives Himself as Well", Sunday Express, 29 Sep. 1946.

${ }^{67}$ See, for example, 'Neville Heath: Exclusive Picture', Sunday Pictorial, 4 Aug. 1946, p. 3; 'Story of Walk with Chine Girl', London Evening Standard, 6 Aug. 1946.

68 'Chine Murder: Decision on Charge Soon', 16 Jul. 1946; 'Story of Heath's Letter to Public Told in Court', London Evening Standard, 29 Jul. 1946, p. 8; 'Heath: "Woman Victim Lashed 17 Times"', London Star, 29 Jul. 1946, p. 4.

69 “'Chine Murder Report Ready', News of the World, 14 Jul. 1946; D. Adcock, 'Chine Slayer Was "Jekyll \& Hyde", People, 14 Jul. 1946.

70 'Ex-Wren Fought for Life in Chine, Court is Told', News Chronicle, 7 Aug. 1946; 'Doreen Marshall Was Victim of Sadist', London Evening News, 6 Aug. 1946; 'Heath Sent for Trial on Hotel Murder Charge', Daily Graphic, 7 Aug. 1946, p. 3.

71 'Heath: Brutal Murder', London Evening News, 24 Sep. 1946, p. 1; 'Heath Case KC Says “Almost a Monstrosity"', London Star, 24 Sep. 1946, p. 1; D. Camp, 'Doctors Clash on Sanity of Heath', News Chronicle, 26 Sep. 1946, p. 1; 'Heath to Die: Judge Tells Jury "Mere Lust is Not Insanity"', London Evening Standard, 26 Sep. 1946.
} 
of the murders revealed in that day's evidence. ${ }^{72}$ Of the national dailies, the Express pushed the sadism angle most prominently, including a feature in which an unnamed 'psychologist' explained to readers what 'psychopath' and 'sadist' meant. ${ }^{73}$ Some of the middlebrow daily papers, such as the Graphic and the News Chronicle, were less interested in the sadistic elements of the murders, but gave more space to the debate between medical experts concerning Heath's sanity - minus, however, the argument that it might have been caused by his war service. ${ }^{74}$ The Mail, the Herald and the Mirror all featured revelations about Heath's 'night club' lifestyle on the day following the verdict, ${ }^{75}$ but still gave ample space to the evidence of Heath's sadism.

Sadism was clearly an intriguing concept for the popular press. The Sunday Dispatch, rather left behind by the scoops of others, published an article giving readers background to the 'numerous references to sadism' in the trial, essentially a short biography of the Marquis de Sade. ${ }^{76}$ But discussion of 'sadism' was far from unknown at this time. In fact, it had often been used by the press throughout 1945 and 1946 when describing the war crimes of German and Japanese forces. Sadism was explicitly used to describe German soldiers, guards and doctors involved in the concentration and extermination camps, ${ }^{77}$ and stories of Nazi crimes were a significant part of the popular press between the liberation of the Belsen concentration camp in April 1945 and the hanging of German war criminals after the Nuremberg judgement in October 1946. The trial of Josef Kramer, 'the beast of Belsen', was heavily reported, ${ }^{78}$ and

\footnotetext{
${ }^{72}$ See, for example: 'Heath - Brutal Murder', London Evening News, 24 Sep. 2016, p. 1; 'Heath K.C. Pleads "Partial Insanity", London Evening Standard, 25 Sep. 1946, p. 1;

73 'Heath - "The kind who lives for the moment, and deceives himself as well"', Daily Express, 29 Sep. 1946.

74 'Insanity Pleas Not a Refuge', Daily Graphic, 27 Sep. 1946, p. 3; 'Three Points Put to Heath Trial Jury', News Chronicle, 27 Sep. 1946, p. 3.

${ }^{75}$ Guy Ramsey, 'Heath, Man-About-Town at 15, Played Lone Wolf to the End', Daily Mail, 27 Sep. 1946, p. 3; 'Masquerade Life of Heath', Daily Herald, 27 Sep. 1946, p. 8; 'Heath in a Club Party - With All the Charm Turned On', Daily Mirror, 27 Sep. 1946, p. 3.

${ }^{76}$ A. Tomkins, 'Sadism', Sunday Dispatch, 29 Sep. 1946, p. 4.

77 “"Buchenwald Beast” Hid in PoW Cage', Daily Mail, 30 Jun. 1945, p. 1; V. Evans, 'Briton Ate Grass in Belsen Camp', Daily Express, 21 Sep. 1945, p. 4; 'Nazi Chief Killer Captured', Daily Mail, 29 May 1946, p. 1 ${ }^{78}$ In depth stories included: Richard Rumbold, 'Beast of Belsen's Girl Violinist', News of the World, 13 May 1945, p. 5; R. Churchill, 'The Women Without Remorse', Daily Mail, 15 Sep. 1945.
} 
a run of other European trials and stories kept these crimes in the British press throughout the period. One typical story reminded readers of the assassination of Reinhard Heydrich a 'tall, thin, perverted, narrow-faced sadist who incarnated in his single person the finest flower of their kultur' ${ }^{79}$ From September 1945, stories about Japanese prisoner of war and internment camps supplemented reports from Europe and depicted, in the words of one report, 'a record of cruelty, bestiality and sadism such as the world has rarely seen' ${ }^{80}$ The climax of the Nuremberg trials coincided with that of Heath's Old Bailey hearing, with newspapers often featuring stories on the two cases side by side. In fact, Heath and the Nuremberg war criminals all hanged on 16 October $1946 .{ }^{81}$ This wider discussion of sadism also saw the term become more current in other contexts. In December 1945, prison officers at Wormwood Scrubs were accused of using 'sadistic violence' in punishing a young prisoner. ${ }^{82}$ The Daily Mirror's film critic, Reg Whitley, was keen on using it to describe characters such as Vivien Leigh's in the film Caesar and Cleopatra, 'a scheming, seductive and sadistic-minded minx'. ${ }^{83}$ Similarly, Lionel Hale called a Patrick Hamilton 'practised hand' in 'the sadistpsychological' when reviewing his new play in the Daily Mail. ${ }^{84}$ Intriguingly, Hamilton would go on to write a trilogy of novels featuring a character based on Heath. ${ }^{85}$

Sadism may have had broader currency as a descriptive term for apparently motiveless violence and evil, but at the precise moment when Heath was in the dock it would have been a term most obviously related to enemy war crimes. In the immediate postwar

\footnotetext{
${ }^{79}$ G. Ramsey, 'Vengeance on the Village Green', Daily Mail, 22 May 1946, p. 2.

${ }^{80}$ A. Noyes Thomas, '5,200 Britons Have Left Singapore', News of the World, 16 Sep. 1945, p. 1; 'Helpless Soldiers Bayoneted, Tortured', Daily Mail, 10 Sep. 1945, p. 1; see also 'Each Mile Five More men Died', Daily Mail, 22 Nov. 1945, p. 4; 'The Crime of Bekasi', Daily Express, 2 Jan. 1946, p. 2; Fred Aldridge, 'Japanese Orgy of Sadism', News of the World, 13 Jan. 1946, p. 1.

${ }^{81}$ See 'All 11 Nazi War Leaders Executed Before 2.15 am', Daily Mirror, 16 Oct. 1946.

82 'Borstal Death: Ede to Act', Daily Mirror, 21 Dec. 1945, p. 1; 'Borstal Officers Plead "Hear Us”: On

"Sadism" Charge', Daily Mail, 22 Dec. 1945, p. 3

${ }^{83}$ R. Whitley, ‘ $£ 1,250,000$ Film to Out Britain Right into U.S. Market', Daily Mirror, 12 Dec. 1945, p. 5; Whitely was clearly fond of using 'sadism' to descrive any evil character in a film, his reviews from 1 February, 17 May, and 31 May 1946 do likewise.

84 'Formula for Murder', Daily Mail, 27 Mar. 1946, p. 3.

${ }^{85}$ Hamilton's novels are The West Pier (1951), followed by Mr Stimpson and Mr Gorse (1953) and Unknown Assailant (1955).
} 
period, many of the terms now used to understand the extent and nature of the Nazi actions against Jews and others had yet to be fully codified. Historians have extensively examined the images and narratives generated by the liberation of Belsen by British forces in order to map how an of the Holocaust as a separate and systematic racial war of extermination emerged in postwar British culture. ${ }^{86}$ British press treatment of the liberation of Belsen tended to elide the genocidal violence of the Nazi war against European Jews with a broader narrative of war crimes and barbarism. This is not to say that the British public were unaware of Nazi war crimes, rather that there was a conceptual struggle to separate out the genocidal violence against European Jews with the wider history of Nazi war crimes inflicted throughout the war. As Tony Kushner puts it, in the immediate postwar period, Belsen was 'understood through the prism of atrocity' ${ }^{87}$

The press treatment of Nazi and Japanese crimes and atrocities conveyed the war's brutality to British readers. Human sadism and evil was placed at the centre of stories which featured monstrous, faceless and racially sterotyped Japanese guards, and a series of Nazi figures each more seemingly evil and sadistic than the last. These stories illustrated the war allowed such evil to flourish, and that such people were the cause of many of the war's worst moments. Discussion of British criminality and the demobilisation of servicemen was happening alongside these stories, and it is hard not to see a common thread of anxiety about the violent impact of war. But British crimes, as we have seen, tended to be depicted as a result of temporary social problems rather than a revealing of deep-seated problems within British manhood. This nationally-specific understanding of the war's potential impact was

\footnotetext{
${ }^{86}$ Particularly relevant are T. Kushner, The Holocaust and the Liberal Imagination; the essays in S. Bardgett and D. Cesarani, eds., Belsen, 1945: New Historical Perspectives (Edgware, 2006); and D. Stone, The Liberation in the Camps:The End of the Holoacust and its Aftermath (New Haven, 2015); for two essays on the early history of British responses, see: D. Cesarani, 'How Post-war Britain Reflected on the Nazi Persecution and Mass Murder of Europe's Jews: a Resassessment of Early Responses', Jewish Culture and History, 12:1-2 (2010), ; and D. Stone, 'The Domesication of Violence: Forging a Collective Memory of the Holocaust in Britain, 1945-46', Patterns of Prejudice, 33:2 (1999), pp. 13-29.

${ }^{87}$ T. Kushner, 'From “This Belsen Business" to "Shoah Business": History, Memory and Heritage, 1945-2000', in S. Bardgett and D. Cesarani, eds., Belsen, 1945: New Historical Perspectives (Edgware, 2006), p. 190.
} 
helped by the press' discussion of war crimes, including the liberation of Belsen and the trials of various war criminals, in ways which highlighted Britain's role in liberating Europe. British justice was celebrated, and German criminals and civilians were depicted as expressing surprise at the tolerant and fair system of justice they were now subject to. ${ }^{88}$ Similarly, the British press reacted to the emerging refugee crisis in central Europe during the winter of 1945-46 with a familiar focus on British responses reflected on the nation's values. As Matthew Frank has put it, the crisis 'allowed the British to hold a mirror up to themselves and, on the whole, they liked what they saw.... An air almost of self-congratulation pervaded discussion of this issue'. ${ }^{89}$ At the same time, the behaviour of British soldiers and airmen occupying Germany was constantly, and obviously, favourably compared with the enemy, even to the extent of glossing over clearly criminal behaviour. For example, in August 1945, a court martial cleared three RAF officers of raping young German women at gun point. Their defence brief argued that 'although it might well be a disgraceful affair', there wasn't evidence to convict and 'urged the Court to realise that the events which were the subject of charges occurred not in the calm of day but in the heat of battle'. The incident occurred during the British advance in April, although after a night of drinking in the mess rather than in the 'heat of battle'. 90 The press also carried stories defending the Red Army's 'rough' treatment of the civilian population. ${ }^{91}$

Germany and Japan had of course been demonised in the British press during the war, and there was an understandable reticence in portraying British soldiers' actions in Germany in a bad light. There was a wider significance to the locating of British values of justice and fairness alongside the discussion of atrocity and sadism, however, and that was to place

\footnotetext{
${ }^{88}$ See 'British Justice Surprises Nazis: Beslen Victim Tells of Camp Horrors', News of the World, 23 Sep. 1945, p. 1.

${ }^{89}$ M. Frank, Expelling the Germans: British Public Opinion and the Post-1945 Population Transfer in Context (Oxford, 2008), p. 225.

90 'German Girls Accuse R.A.F. Officers', News of the World, 26 Aug., 1945, p. 5.

91 'M.P.'s Denial of “Cruel Russians” Story', News of the World, 14 Oct. 1945, p. 1.
} 
discursive distance between the war experience of Britain and that of the enemy, and to stress that the evil that war caused, or let flourish, was a 'European' or Asian phenomenon, and not a British one. This portrayal of atrocity and sadism meant that when Heath was depicted as a deranged, amoral sadist, readers had a context in which to place him: a context which made Heath understandable as an example of the evil that caused such horrors, and not as an example of the typical British serviceman.

Sadism was not the only way the popular press sought to understand Heath. The press picked apart every aspect of his life. They were particularly keen to provide details of his past criminal and sexual life. The emphasis on his record of criminality also served to create further distance between Heath's murders and the idea that his 'perversion' had been induced by the war. He was presented as both a uniquely monstrous individual and a recognisable criminal type. Heath's criminal past was mentioned early in the manhunt, ${ }^{92}$ but became a focus of attention after the trial when the popular Sundays competed with different Heaththemed exclusives. Reynold's News secured an interview with Heath's mother, and used her memories of Heath as a 'good' and 'kind' boy as a counterpart to its account of Heath's psychosexual pathology, which linked Heath's sadism to his dishonesty. ${ }^{93}$ The People also saw Heath's sadism and criminality as of a piece with his 'colossal, over-riding vanity'. ${ }^{94}$ The News of the World also dug deep into Heath's war service, its reporter telling the reader, 'I have talked to a number of men who flew with Heath. They say he was a good but nervous pilot, and certainly no hero'. Over Holland, 'enemy counter-action was negligible', but Heath 'suddenly ordered the crew to bail out. The men were astounded'. ${ }^{95}$ This was at odds with the self-depiction of Heath provided in the Sunday Pictorial, which printed the letter Heath wrote to friends whilst in prison. Heath declared that "my war record, as a fighter pilot, is a good

\footnotetext{
92 'The "Tragic Record” of Geo. Heath', London Evening News, 25 Jun. 1946, p. 1.

${ }^{93}$ B. Minns, 'Heath - I talk to his Mother', Reynold's News, 29 Sep. 1946, p. 4.

${ }_{94}$ A.W. Helliwell, 'Yard Feared Chain of Heath Slayings', The People, 29 Jun. 1946, p. 3.

95 'Heath's Life of Masquerade Laid Bare', News of the World, 29 Sep. 1946, p. 5.
} 
one, and it may be that some of the experiences of those frenzied years have played a part in bringing me where I am today'. ${ }^{96}$ Martin Francis has argued that Heath's masquerade as a 'flyer', which included posing as a Squadron Leader and being arrested for wearing decorations he was not entitled to, would have been 'unsettling' for a public which had invested so much in the positive image of the airman. ${ }^{97}$ But Heath was rarely depicted as a 'real' flyer. Even his own letters were contradicted in the Pictorial. The exposure of his life of deceit, impersonation and fraud served to distance him from bona fide airmen, and perhaps even to underpin the continued worth of 'real' flyers. Moreover, the opportunities wartime gave to fraudulent masquerade was a recurrent theme of crime reportage. ${ }^{98}$

As well as Heath's sadism and criminality, the press also gleefully seized on the evidence of Heath's sexual success with women. This is unsurprising, as sex was a staple of British popular newspapers, particularly the Sunday press. In the Heath case, women were discussed as his sexual victims: not just Margaret Gardner and Doreen Marshall, but also the key witness Yvonne Symmonds and apparently innumerable other sexual partners. Heath was presented as immensely attractive and holding an almost abnormal appeal for women. His physical allure was highlighted from the beginning of the case, being described as handsome, tanned, well-built, and very well-groomed. ${ }^{99}$ The Sunday Pictorial, perhaps keen to build up their readers' interest in the man ahead of their planned post-trial scoop, emphasised Heath's physical charms in the lead up to the trial. ${ }^{100}$ Heath's sexual power was depicted as verging on the mesmeric and after the trial, the Daily Mirror and Daily Express both printed a closeup of Heath's eyes, described as capable of 'fascinating' women. ${ }^{101}$ This was matched by the

\footnotetext{
96 “"I Cannot Believe I Did It” - Heath', Sunday Pictorial, 29 Sep. 1946, p. 6.

${ }^{97}$ Francis, The Flyer, pp. 150-1.

${ }^{98}$ See, for example, 'Thieves Were on Full Time', Daily Herald, 24 Apr. 1946, p. 1; 'Masquerade to Win Bride', 31 Mar. 1946, p. 1.

99 'Girl Witness Tells Court of Her Hotel Visit with Heath', News of the World, 4 Aug. 1946, p. 3; 'Heath in the Dock', London Star, 3 Jul. 1946, p. 1; 'Heath Can't Get His Steak Now', Sunday Pictorial, 18 Aug. 1946, p. 4 100 'Behind the Scenes in the Heath Case', Sunday Pictorial, 11 Aug. 1946, p. 4.

101 'His Eyes Glowed', Daily Mirror, 27 Sep. 1946, p. 5; P. Hoskins, 'The Strange Life and Crimes of Neville George Heath', Daily Express, 27 Sep. 1946, p. 3.
} 
Daily Mail's remarkable taxonomic image of Heath's face: headed 'the face any woman would trust', it labelled Heath's 'good straight nose', 'sensitive mouth', and 'firm cleft chin' as evidence of his extraordinary handsomeness. ${ }^{102}$ The popular press further signalled Heath's heterosexual attractiveness by describing the throngs of women who came to the court, ignoring the fact that less than a third of those in the public gallery on the first day of Heath's trial were women. ${ }^{103}$ When Heath was executed, ${ }^{104}$ the Evening Standard photograph showed a mixed crowd gathering outside Pentonville, but the Star cropped the photograph to show a smaller portion of those assembled, and captioned it, 'Women Waited for Heath's End'. ${ }^{105}$ This alleged female interest was presented as sexually charged, with the Graphic told its readers of women at the trial who 'peered, craned and edged - all to see Heath'. ${ }^{106}$ Before the trial, the People declared that 'rarely have women been so fascinated by a murder trial. Since the day the case hit the headlines they have trooped to see this handsome blueeyed young man with the cultured voice and the well-kept finger-nails' ${ }^{107}$ These portrayals of feminine enthralment to Heath served both to further stoke public interest in the case, and to depict both his victims and the female crowd as agentless subjects, unable to resist Heath's allure.

Discussion of the women at the heart of the case further entrenched the idea of Heath as a sexual monster. Margaret Gardner was presented as a sexually available bohemian residing in London's demi-monde, a perhaps 'natural' companion of a man of Heath's

\footnotetext{
${ }^{102}$ G. Ramsey, 'Heath, Man-About-Town at 15, Played Lone Wolf to the End', Daily Mail, 27 Sep. 1946, p. 3. 103 'Women are Waiting 13 Hours for Heath Case', Daily Herald, 24 Sep. 1946, p. 1; 'All-Night Queue...', News Chronicle, 24 Sep. 1946, p. 1.

${ }^{104}$ For the wider relevance of Heath's execution, see C. Langhamer, “"The Live Dynamic Whole of Feeling and Behaviour": Capital Punishment and the Politics of Emotion, 1945-1957', Journal of British Studies, 51:2 (2012), pp. 416-441.

105 'Mrs Van der Elst Fined', Evening Standard, 16 Oct. 1946, p. 1; 'Women Waited for Heath's End', London Star, 16 Oct. 1946, p. 6

106 '2 New Witnesses in Heath Trial', Daily Graphic, 25 Sep. 1946, p. 3.

107 'World-wide Interest in the Heath trial', The People, 15 Sep. 1946, p. 5.
} 
type. ${ }^{108}$ Doreen Marshall was presented very differently, as an 'innocent' reluctant to become sexually involved with Heath. ${ }^{109}$ Marshall was depicted as a holidaying young woman, attracted to this fascinating man but reluctant to take the final step towards sexual activity. Just as the details of Margaret Gardner's life helped to create the lurid impression of Heath's sexually-charged London life, so the opposite portrayal of Doreen Marshall deepened the image of Heath as a deranged, sadistic predator. The press also placed great scrutiny on Yvonne Symonds, and during the preliminary hearings as well as the trial, Symonds' photograph was printed in several newspapers, and even appeared on the front page of the Daily Mirror in the middle of the trial coverage. ${ }^{110}$ She was a key witness to Heath's movements, but press interest centred on her status as the only one of Heath's many sexual partners to speak in the trial. For the newspapers, Symonds embodied the unknown 'hundreds' of Heath's 'willing victims', 11 depicted as both duped by Heath and unable to resist him, but her sexual experience with Heath made her exciting copy and the press duly printed her story and image for readers' titillation. ${ }^{112}$

Crime and sexuality were interlinked in the Heath case, just as they were in the stories of returning servicemen murdering unfaithful wives. In those cases, the men were portrayed as having some sort of moral right to retribution. It is easy to see the press coverage of these earlier trials as part of the wider discursive regulation of female sexuality that marked the war

108 'Initial "K" Handkerchief is New Hotel Murder Clue', London Evening Standard, 26 Jun. 1946, p. 1; 'Tied Girl: Yard Seek Man', Sunday Dispatch, 23 Jun. 1946, p. 5; ‘6ft Man Sought in Hotel Crime', People, 23 Jun. 1946, p. 1.

109 'Heath: Story of Midnight Walk', London Evening News, 6 Aug. 1946, p. 4; 'Story of Walk with Chine Girl', London Evening Standard, 6 Aug. 1946, p. 1; 'Heath in a Club Party - With All the Charm Turned On', Daily Mirror, 27 Sep. 1946, p. 5.

110 'Heath in Court on Two Murder Charges', Daily Graphic, 30 Jul. 1946, p. 3; 'Girl in Heath Case', Daily Mirror, 25 Sep. 1946.

111 'Heath's Life of Masquerade Laid Bare', p. 5. See, also, 'Story of Heath's Letter to Police Told in Court', London Evening Standard, 29 Jul. 1946, p. 8; 'Girl Tells of 24-hour Romance with Neville Heath: Proposed Marriage - Vanished', Daily Herald, 30 Jul. 1946, p. 3; H. de Winton Wigley, 'Heath Accused of Two Murders', News Chronicle, 30 Jul. 1946, p. 2; 'Heath Defence Move Startles Court', News Chronicle, 25 Sep. 1946, p. 3; '2 New Witnesses in Heath Trial', Daily Graphic, 25 Sep. 1946, p. 3; 'Yvonne Symonds Says “The Heath I Knew Was Courteous and Kind", Daily Mail, 25 Sep. 1946, p. 3;

112 'Heath Listens to Girl', Daily Herald, 30 Jul. 1946, p. 1; 'Heath Defence Move Startles Court', News Chronicle, 25 Sep. 1946, p. 3; 'Girl Witness Tells Court of Hotel Visit with Heath', News of the World, 4 Aug. 1946, p. 3; 'Heath: Girl's Story', London Star, 24 Sep. 1946, p. 12. 
years, whether it was criticising 'good time girls' ${ }^{113}$ or passing anxious comment on the sexual threat that strong, glamorous American and Canadian servicemen posed to the fidelity of servicemen's wives. ${ }^{114}$ In the Heath case, however, female sexuality was presented as passive and largely blameless in the face of Heath's sexual power. If the case offered any warning to young women, it was to be wary of men who contravened 'temperate' models of masculinity. There was some criticism of the state of British society's morals as revealed in the Heath case, but it is striking how isolated these pieces linking the Heath case with wider criticisms of sexual morality were. The Daily Mail called Heath the 'incarnation of war-time and post-war vices', ${ }^{115}$ and in August and September, alongside the Heath coverage, the News of the World printed letters by people concerned about the effects of the war on sexual morality. One writer declared their hope 'that the Heath trial will be a lesson for the pick-up girl, and the authorities will do more to protect the morality of the people'. ${ }^{116}$ Of course, readers' letters played an ambiguous role in newspapers, and their provenance, veracity or representativeness is impossible to establish. ${ }^{117}$

[Line break]

Heath's sadism, criminality, and sexual power combined to create an image of a truly exceptional man. In the aftermath of the war, there were clear anxieties about postwar criminality, the propensity of humans to commit terrible violence, and sexual morality. The Heath case had the potential to open up debate about the nature of postwar Britain and the unpleasant psychological effects of war. Instead, he was portrayed as unique, evil, and far

\footnotetext{
${ }^{113}$ S.O. Rose, 'Sex, Citizenship and the Nation in World War II Britain', American Historical Review 103:4 (1998), pp. 1147-1176; A. Bingham, 'The British Popular Press and Venereal Disease During the Second World War', Historical Journal, 48:4 (2005), 1055-1076; M. Grant, 'Citizenship, Sexual Anxiety and Womanhood in Second World War Britain: the Case of the Man with the Cleft Chin', in S. Nicholas and T. O'Malley, eds., Moral Panics, Social Fears and The Media: Historical Perspectives (London: Routledge, 2013), pp. 177-90. ${ }^{114}$ See D. Reynolds, Rich Relations: The American Occupation of Britain, 1942-1945 (London, 1995), chapters 15 and 23.

115 Ramsey, 'Heath, Man-About-Town at 15, Played Lone Wolf to the End'.

${ }^{116}$ Letter, News of the World, 29 Sep. 1946.

${ }^{117}$ Bingham, Family Newspapers?, p. 9.
} 
removed from other British men who did share his character, tastes, or sensibilities. Indeed, as we have seen, a more natural comparison to Heath, anyone reading a Sunday newspaper the weekend following the trial, would have been found on trial in Nuremberg. The Heath case demonstrates how the memory of the Second World War was discussed in the immediate postwar period. Placed in the context of other debates about crimes and the discussion of wartime atrocities committed by the enemy, we can see that the Heath case was depicted as being largely disconnected to the war and certainly not as an indicator that the war had caused lasting psychological damage to British servicemen and civilians. Criminal cases had been a focus of anxieties about the impact of the war in 1945 and 1946, although these concerns focused on disruption to society rather than more lasting or fundamental problems. There was no great anxiety that war trauma had led to increased lawlessness, for example. Neville Heath had a record of active service and his insanity plea was based in part on the blackouts he claimed to have been experiencing ever since a traumatic episode in the war. This plea was ignored in court, and virtually silenced in the press coverage. Instead, Heath's 'sadistic' violence and sexual power was placed at the centre of the coverage, ensuring that Heath's violence was presented very differently from other British crimes of the 1945-46 period. For newspaper readers, Heath's sadism would have understandable in the context Nazi war crimes rather than the actions of fellow servicemen. Such sadistic acts were further presented as a phenomenon combatted by British soldiers, rather than something they might be associated with. As such, the Heath case highlights how concerns about the impact of the war could be resolved by further emphasising, through the figure of Heath himself, the essential difference between Britain and its enemies.

The press' articulation of British war memory was not solely reliant on its ambiguous discussion of violence and trauma. The war was celebrated at this time, whether through the discussion of Britain's role in ending Nazi barbarism (as we have seen), revelation of 
previously 'hidden' stories of adventure or heroism, or in the reporting on national ceremonies. During the short span of the Heath trial, for example, the press reported not only on the Nuremberg trial, but the Government-organised victory parade, ${ }^{118}$ and the Britain Can Make It exhibition, which like its obvious namesake, the famous wartime documentary Britain Can Take It, was designed to display British resilience: this time to demonstrate the nation's ability to recover from the war through a high-quality export-led manufacturing economy. ${ }^{119}$ This positive memory of the war was aided by the narrative choices made in stories which had to potential to disrupt such meanings, as in the Heath case. Histories of Western Europe in the immediate postwar period have highlighted how the cultural memory of the war was shaped and instrumentalised to perform the cultural work of reconstructing the nation-state, traditional gender roles, and social 'normality'. Selective memory of the war underpinned recovery from the trauma of defeat, occupation and deep social divisions. Britain did not experience upheaval on the same scale, but the cultural memory of the Second World War was constructed in a comparable, if less extreme, way: built on the selective appropriation of positive elements of the memory of the Second World War. This form of cultural memory was actively constructed within popular culture by celebrating the positive and negating the negative aspects of wartime experience. The press coverage of the Heath trial demonstrates how this was achieved.

\footnotetext{
${ }^{118}$ A.W. Helliwell, 'Ghosts Marched, Too, in this Parade of Proud Memories', The People, 9 Jun. 1946, p. 1; see also 'London Crowd Went Mad Last Night', Sunday Pictorial, 9 Jun. 1946, p. 2.

119 'Dream at Show', London Star, 25 Sep. 1946, p. 5; 'Britain Shows She Can "Make It"', News of the World, 22 Sep. 1946, p. 3
} 